\title{
Practical Guidelines for Small-Volume Additions of Uninhibited Water to Waste Storage Tanks (U)
}

by

B. J. Wiersma

Westinghouse Savannah River Company

Savannah River Site

Aiken, South Carolina 29808

T. C. Hsu

Westinghouse Savannah River Company

SC USA

P. E Zapp

Westinghouse Savannah River Company

SC USA

J. A. Pike

Westinghouse Savannah River Company

SC USA

\section{DISCLAIMER}

\begin{abstract}
This report was prepared as an account of work sponsored by an agency of the United States Government. Neither the United States Government nor any agency thereof, nor any of their bility for the accuracy, completeness, or or implied, or assumes any legal liability or responsiprocess disclosed, or represents that its use ulness of any information, apparatus, product, or ence herein to any specific commercial use would not infringe privately owned rights. Refermanufacturer, or otherwise does not product, process, or service by trade name, trademark, mendation, or favoring by the United States Govitute or imply its endorsement, recomand opinions of authors expressed herein do Government or any agency thereof. The views United States Government or any agency thereof necessarily state or reflect those of the
\end{abstract}

A document prepared for 1995 NACE INTERNATIONAL ANNUAL CONFERENCE CORROSION95 at Orlando, from 03/26/95 - 03/31/95.

\section{DOE Contract No. DE-AC09-89SR18035}

This paper was prepared in connection with work done under the above contract number with the U. S. Department of Energy. By acceptance of this paper, the publisher and/or recipient acknowledges the U. S. Government's right to retain a nonexclusive, royalty-free license in and to any copyright covering this paper, along with the right to reproduce and to authorize others to reproduce all or part of the copyrighted paper. 


\section{DISCLAIMER}

Portions of this document may be illegible in electronic image products. Images are produced from the best available original document. 


\section{DISCLAIMER}

This report was prepared as an account of work sponsored by an agency of the United States Government. Neither the United States Government nor any agency thereof, nor any of their employees, makes any warranty, express or implied, or assumes any legal liability or responsibility for the accuracy, completeness, or usefulness of any information, apparatus, product, or process disclosed, or represents that its use would not infringe privately owned rights. Reference herein to any specific commercial product, process, or service by trade name, trademark, manufacturer, or otherwise does not necessarily constitute or imply its endorsement, recommendation, or favoring by the United States Government or any agency thereof. The views and opinions of authors expressed herein do not necessarily state or reflect those of the United States Government or any agency thereof.

This report has been reproduced directly from the best available copy.

Available to DOE and DOE contractors from the Office of Scientific and Technical Information, P.O. Box 62, Oak Ridge, TN 37831; prices available from (615) 576-8401.

Available to the public from the National Technical Information Service, U.S. Department of Commerce, 5285 Port Royal Road, Springfield, VA 22161. 
WSRC-MS-94-0582

\section{PRACTICAL GUIDELINES FOR SMALL-VOLUME ADDITIONS OF UNINHIBITED WATER TO WASTE STORAGE TANKS (U)}

by

T. C. Hsu, B. J. Wiersma, P. E. Zapp, and J. A. Pike

Westinghouse Savannah River Company

Savannah River Site

Aiken, SC 29808

A paper proposed for presentation at the 1995 NACE International Annual Conference CORROSION/95 Orlando, Florida

March $26-31,1995$

and for publication in the proceedings

The information contained in this article was developed during the course of work under Contract No. DE-AC09-89SR18035 with the U.S. Department of Energy. By acceptance of this paper, the publisher and/or recipient acknowledges the U. S. Government's right to retain a nonexclusive, royalty-free license in and to any copyright covering this paper along with the right to reproduce, and to authorize others to reproduce all or part of the copyrighted paper. 


\title{
Practical Guidelines for Small-Volume Additions of Uninhibited Water to Waste Storage Tanks
}

\author{
T. C. Hsu, B. J. Wiersma, P. E. Zapp, and J. A. Pike \\ Westinghouse Savannah River Company \\ P. O. Box 616 \\ Aiken SC 29802
}

\begin{abstract}
Allowable volumes of uninhibited water additions to waste tanks are limited to volumes in which hydroxide and nitrite inhibitors reach required concentrations by diffusion from the bulk waste within five days. This diffusion process was modeled conservatively by Fick's second law of diffusion. The solution to the model was applied to all applicable conditions which exist in the waste tanks. Plant engineers adapted and incorporated the results into a practical working procedure for controlling and monitoring the addition of uninhibited water. Research, technical support, and field engineers worked together to produce an effective solution to a potential waste tank corrosion problem.
\end{abstract}

Keywords: Pitting, Carbon Steel, Radioactive Waste, Inhibitors

\section{INTRODUCTION}

Pitting is the likely corrosion mode in carbon steel exposed to the dilute alkaline salt solutions contained in some high-level radioactive waste tanks. Because of the rapid absorption of atmospheric carbon dioxide in actively ventilated waste tanks, the hydroxide concentration near the surface of the waste can be driven quickly to less-thanprotective values. This situation is considered most deleterious to the steel immediately above the liquid-vapor interface. Pitting corrosion of carbon steel may occur if the $\mathrm{pH}$ of a solution in contact with the steel is less than 10 [1]. Further, solutions containing corrosive anions such as nitrate, sulfate, or chloride may require a $\mathrm{pH}$ of up to 14 to prevent pitting. Even aqueous solutions of $10 \leq \mathrm{pH} \leq 13$ may not be sufficient to prevent localized attack [2].

Uninhibited water entering waste tanks is likely to have $\mathrm{pH}$ values in the near neutral range. Due to the lower specific gravity of the uninhibited water in comparison to 
the bulk waste supernate, it is assumed that the uninhibited water forms a separate layer above the waste. This layer is conservatively assumed to not mix convectively with the tank contents. Water in this uninhibited layer will remain corrosive until inhibitor concentrations rise to protective values by diffusion from the waste. Such a model may explain the observation of cooling coil pitting failures in waste tanks to which large volumes of uninhibited water were added to facilitate waste removal. Currently, large volumes of water which are added to the tanks are inhibited by either $0.01 \mathrm{M}$ sodium hydroxide and $0.011 \mathrm{M}$ sodium nitrite or $1 \mathrm{M}$ hydroxide to prevent pit initiation.

Contrary to the experience of waste removal operations with large-volume water additions, no adverse effects have been observed from the routine small-volume additions of uninhibited water at the Savannah River Site. It is postulated that such small -volume additions attain protective concentrations of inhibitor(s) sufficiently quickly to prevent pit initiation. This paper describes a model which was developed to relate the volume of uninhibited water additions to protective inhibitor levels. The model is used to recommend maximum allowable volumes of uninhibited water that may be added to waste tanks.

\section{MODELING}

Several assumptions were made in modeling the diffusion process. The diffusion of finite-concentration ions in multicomponent electrolytes is a complex subject [3]. However, a reasonable lower bound for the diffusion coefficient of nitrite at $25^{\circ} \mathrm{C}$ is $10^{-5}$ $\mathrm{cm}^{2} / \mathrm{s}$. Comparing the ionic conductances of various ions in water indicates that the hydroxide ion diffusion coefficient is approximately three times greater than nitrite. These values will be utilized in the diffusion calculations.

The uninhibited water contains negligible quantities of hydroxide and nitrite. Thus there will be a period of time when the top of the addition layer does not meet the inhibitor requirements. Although pit induction times and growth rates are not well known, the cooling coil failures indicate that the pit growth rates may be as high as 0.15 inches/month ( $3.8 \mathrm{~mm} /$ month). Some period of time is required to initiate pits, and some pits in the early stages of growth may cease growing and repassivate upon the establishment of inhibiting conditions. Based on these considerations, the five-day limit to achieve the required inhibitor concentrations is reasonable.

The objective of the model is to determine the largest water addition for which the required inhibitor concentrations are achieved at the top of the layer in five days. The concentration profile for a diffusing species in a stagnant layer of thickness $L$ can be modeled with Fick's second law for unsteady state diffusion,

$$
\frac{\partial C}{\partial t}=D \frac{\partial^{2} C}{\partial x^{2}}
$$

where $C$ is the concentration and $D$ is the diffusion coefficient. This equation may be solved with appropriate initial and boundary conditions for $L$, given the supernate inhibitor concentration, $\mathrm{C}_{0}$. The initial condition is that the concentration of inhibitor, $\mathrm{C}_{\mathrm{i}}$, is zero throughout the layer. Boundary conditions at time zero are that the inhibitor concentration at the bottom of the addition layer (i.e., $\mathrm{x}=0$ ) equals the supernate inhibitor concentration and that the mass flux $(\mathrm{D} \mathrm{dc} / \mathrm{dx})$ of the inhibitor at the top of the water addition layer (i.e., $x=L$ ) is zero. It is assumed that $C_{0}$ is not reduced by the flux into the addition layer, since the water additions are expected to be much smaller than the waste 
volume. The solution for the diffusion equation is [4]:

$$
\frac{C_{i}}{2 C_{0}}=\sum_{n=0}^{\infty}(-1)^{n} \operatorname{erfc}\left[\frac{L+2 n L}{2 \sqrt{D t}}\right]
$$

Equation 2 was solved iteratively for the thickness of the maximum safe water addition. Table 2 shows the results for situations in which the hydroxide concentration controls the amount of water addition. In this case $C_{i}$ is either $0.01 \mathrm{M}$ or $1 \mathrm{M}$ and $\mathrm{C}_{0}$ depends on the concentration of hydroxide in the supernate. The length $\mathrm{L}$ is converted to gallons by knowing the surface area of the tank. A good approximation is 1 inch (2.54 $\mathrm{cm}$ ) of solution is equivalent to 3500 gallons $(13000 \mathrm{~L})$. Table 3 shows the results for situations in which the nitrite concentration controls the amount of water addition. In this case $C_{\mathrm{i}}$ is either $0.011 \mathrm{M}$ or $0.046 \mathrm{M}$. Qualitatively these results show that the maximum allowable water addition increases with the concentration of the inhibitor anions in the supernate. In addition the maximum allowable volume will increase as the diffusion coefficient increases.

\section{APPLICATION OF THE MODEL TO THE WASTE TANKS}

A wide range of salt concentrations exists in the liquid contents of high-level waste tanks. For example, the concentration of nitrate, which can induce stress corrosion cracking and pitting in carbon steel, ranges from greater than several molar in concentrated storage tanks to as low as $0.01 \mathrm{M}$ in dilute waste which has been prepared for vitrification. These aggressive ion concentrations determine minimum effective inhibitor levels [5]. On the basis of these varied supernate concentrations, four categories of tank chemistry were identified by the their appropriate hydroxide and nitrite inhibitor concentrations (see Table 1).

In Category 1 the hydroxide ion concentration is greater than $1 \mathrm{M}$ and the nitrite concentration is negligible. Thus the water addition is inhibited by hydroxide diffusing in from the supernate. The hydroxide concentration at the top of the layer must be greater than $1 \mathrm{M}$ to prevent pitting.

In Category 2 the hydroxide concentration is also greater than $1 \mathrm{M}$, but the nitrite concentration is greater than $0.02 \mathrm{M}$. For this situation either of the inhibitor requirements mentioned earlier are suitable. If the $0.01 \mathrm{M}$ sodium hydroxide and 0.011 $M$ sodium nitrite requirement is selected, nitrite, due to its slower diffusivity, would control the maximum water addition. There are tanks in which the hydroxide and nitrite ion concentrations are such that taking credit for the nitrite will allow a larger volume of water to be added to the tank. On the other hand, if $1 \mathrm{M}$ sodium hydroxide is selected, the hydroxide concentration will control the maximum water addition.

In Category 3 the supernate hydroxide concentration is between $0.01-1.0 \mathrm{M}$ and the nitrite concentration is greater than $0.02 \mathrm{M}$. In this Category the hydroxide and nitrite jointly inhibit the water addition layer. The concentration of hydroxide must be greater than $0.01 \mathrm{M}$ and the nitrite concentration greater than $0.011 \mathrm{M}$.

In Category 4 the hydroxide concentration in the supernate is less than $0.01 \mathrm{M}$ and the nitrite is greater than $0.02 \mathrm{M}$. The reduction of the hydroxide concentration in the supernate is due to dilution and the reaction of hydroxide with absorbed carbon dioxide [6]. The bulk supernate is inhibited with nitrite depending on the bulk nitrate concentration and temperature [5]. The addition layer should also meet these requirements. It has been determined that the steady state hydroxide concentration in 
these situations is $0.00004 \mathrm{M}(\mathrm{pH}=9.5)$. On the basis of expected nitrate concentrations and temperatures the minimum expected nitrite concentration is $0.046 \mathrm{M}$. Since nitrite diffuses more slowly than hydroxide, it will control the maximum addition volume in this category.

Engineers in the field were consulted as to practical considerations for implementing the results of the model into formal guidelines and procedures. The field engineers considered such aspects as: 1 ) measurability of added solution volumes, 2) unnecessary complexity in requirements, 3) impact on other operations in the tank farm and 4) included all situations that exist in the tanks. After several discussions between technical support, field and research engineers, the following recommendations for small volume additions of uninhibited water were made. The recommendations were made on the basis of current and expected tank chemistries.

(1) In any consecutive 5-day period, the cumulative additions (transfers) of uninhibited water to a Category 4 tank shall not exceed 2000 gallons (7600 L). Once the 2000-gallon (7600-L) limit is reached, no further addition may be made for 5 days without consulting with and getting directions from the engineer responsible for monitoring the tank chemistry. The 5-day period begins with the first uninhibited water addition to the waste tank.

(2) In any consecutive 5-day period, the cumulative additions (transfers) of uninhibited water to a Category 1,2, or 3 tank, other than those specified in item (3), shall not exceed 4000 gallons $(15000 \mathrm{~L})$. Once the 4000 -gallon $(15000-\mathrm{L})$ limit is reached, no further addition may be made for 5 days without consulting with and getting directions from the tank chemistry engineer. The 5-day period begins with the first uninhibited water addition to the waste tank.

(3) For tanks with too little supernate to be sampled, consultation with the tank chemistry engineer for direction is needed before each transfer.

(4) If in doubt or if these guidelines are anticipated or discovered after the fact to be exceeded, consultation with the tank chemistry engineer is required for directions or remedial actions, as soon as practical and no later than the next working day.

The limits on additions that were placed in the procedures contain a high degree of conservatism. From the diffusion equation it can be shown that for the volumes chosen, the supernate concentration is only slightly greater than the required inhibitor concentration at the top of the layer. Most of the tanks will have a much larger concentration gradient and therefore be inhibited before the five-day limit expires. The procedures do however allow the field engineers more control and flexibility over the additions of uninhibited water.

\section{CONCLUSIONS}

Uninhibited water additions to waste tanks should be limited to volumes in which hydroxide and nitrite will reach corrosion-inhibiting concentrations within five days. These volumes were calculated from a solution to Fick's second law of diffusion. The solution was applied to the specific chemistry categories which exist in the SRS tank farm. Practical guidelines for small volume additions were finalized by technical support engineers and incorporated practical considerations from the field engineers. As a result, these guidelines were readily accepted into the operations working procedure. Research, technical support, and field engineers worked together to produce an effective solution to a potential waste tank corrosion problem. 


\section{ACKNOWLEDGMENTS}

The authors wish to thank M. J. Rea, P. W. Norris, J. E. Griffiths, E. D. Lee, and M. A. Ceravolo for their contributions into the practical operations considerations.

\section{REFERENCES}

1. K. R. Trethewey and J. Chamberlain, Corrosion: For Students of Science and Engineering, Longman Scientific and Technical, Essex (1988) p. 233.

2. J. W. Congdon, "Inhibition of Nuclear Waste Solutions Containing Multiple Aggressive Anions", Materials Performance 21, 34 (1988).

3. R. C. Reid, J. M. Prausnitz, and B. E. Poling, The Properties of Gases and Liquids, 4th ed., McGraw-Hill Book Co., New York (1987) p. 620.

4. V. G. Jenson and G. V. Jeffereys, Mathematical Methods in Chemical Engineering, 2nd ed., Academic Press, London (1977) pp. 267-269.

5. P. E. Zapp and D. T. Hobbs, "Inhibiting Pitting Corrosion in Carbon Steel Exposed to Dilute Radioactive Waste Slurries," CORROSION/92 paper no. 98, (Houston, TX: NACE International, 1992). 
Table 1. Required Inhibitor Concentrations

\begin{tabular}{cllc} 
Category & Inhibitor(s) & \multicolumn{1}{c}{$\mathrm{C}_{\mathrm{o}}$} & $\mathrm{C}_{\mathrm{i}}$ \\
1 & Hydroxide & $>1 \mathrm{M}$ & $1 \mathrm{M}$ \\
2 & Hydroxide & $>1 \mathrm{M}$ & $1 \mathrm{M}$ \\
& $\begin{array}{l}\text { or } \\
\text { Hydroxide }\end{array}$ & $>1 \mathrm{M}$ & $0.01 \mathrm{M}$ \\
& Nitrite & $>0.02 \mathrm{M}$ & $0.011 \mathrm{M}$ \\
& Hydroxide & $0.01-1 \mathrm{M}$ & $0.01 \mathrm{M}$ \\
3 & Nitrite & $>0.02 \mathrm{M}$ & $0.011 \mathrm{M}$ \\
& Hydroxide & $<0.01 \mathrm{M}$ & $0.00004 \mathrm{M}$ \\
& Nitrite & $>0.046 \mathrm{M}$ & $>0.046 \mathrm{M}$
\end{tabular}

Table 2. Maximum Water Additions to Waste Tanks with Hydroxide as the Diffusion Controlled Species

\begin{tabular}{|c|c|c|}
\hline $\mathrm{C}_{\mathrm{i}} / \mathrm{C}_{0}$ & $\mathrm{~L}$ (in.) & Volume (gallons) \\
\hline 1 & 0.96 & 3400 \\
0.8 & 1.63 & 5700 \\
0.67 & 1.94 & 6800 \\
0.5 & 2.3 & 8100 \\
0.4 & 2.56 & 9000 \\
0.33 & 2.78 & 9700 \\
0.25 & 3.08 & 10,800 \\
0.22 & 3.20 & 11,200 \\
0.2 & 3.30 & 11,600 \\
0.1 & 3.93 & 13,800 \\
0.071 & 4.22 & 14,800 \\
\hline
\end{tabular}

Table 3. Maximum Water Additions to Waste Tanks with Nitrite as the Diffusion Controlled Species

\begin{tabular}{|c|c|c|}
\hline $\mathrm{C}_{\mathrm{i}} / \mathrm{C}_{0}$ & $\mathrm{~L}$ (in.) & Volume (gallons) \\
\hline 1 & 0.57 & 2000 \\
0.75 & 1.01 & 3500 \\
0.55 & 1.26 & 4400 \\
0.37 & 1.54 & 5400 \\
0.28 & 1.71 & 6000 \\
0.24 & 1.82 & 6400 \\
0.12 & 2.14 & 7500 \\
0.036 & 2.73 & 9500 \\
0.018 & 3.06 & 10,700 \\
0.011 & 3.28 & 11,500 \\
0.0055 & 3.60 & 12,600 \\
\hline
\end{tabular}

